\title{
Efficacy and Adverse Events of Platelet Transfusion - Product-Specific Differences
}

\author{
Peter Hellstern \\ Institut für Hämostaseologie und Transfusionsmedizin, Klinikum der Stadt Ludwigshafen, Germany
}

\section{Key Words}

Platelet transfusion - Apheresis platelet concentrates . Pooled platelet concentrates - Efficacy · Adverse events . Logistics

\section{Summary}

Two preparations are available for platelet transfusion: single-donor apheresis platelet concentrates (APC) and pooled platelet concentrates (PPC) prepared from 4-6 whole blood units. Clear advantages of APC over PPC are a markedly reduced donor exposure of recipients, and easier logistics when attempting a complete supply with ABO-identical and Rh-compatible platelet concentrates. Regulations should aim at complete $A B O$-identical platelet transfusions because major and minor $\mathrm{ABO}$-incompatible platelet transfusions are probably associated with significantly increased morbidity and mortality. The main advantage of PPC is lower costs. Preparation of PPC is however inevitably accompanied by substantial wastage of plasma and red cells. Only major supraregional blood transfusion centers can guarantee full-coverage supply with ABO-identical and Rh-compatible PPC. Whether APC are more effective than PPC and associated with fewer septic platelet transfusion reactions as shown in some but not all studies, has to be examined in future prospective controlled trials.

\section{Introduction}

Platelet concentrates can be prepared either by plateletpheresis (apheresis platelet concentrates, APC) from single donors or by pooling 4-6 platelet-rich plasma or buffy coat units (pooled platelet concentrates, PPC) from whole blood units. A recent International Forum that reviewed the PLT transfusion

\section{Schlüsselwörter \\ Thrombozytentransfusion - Thrombozytapherese- konzentrate - Gepoolte Thrombozytenkonzentrate . Wirksamkeit · Verträglichkeit · Logistik}

\section{Zusammenfassung}

Für die Thrombozytentransfusion stehen von Einzelspendern gewonnene Thrombozytapheresekonzentrate (TTK) und gepoolte Thrombozytenkonzentrate (GTK) aus jeweils 4 bis 6 Vollblutspenden zur Verfügung. Sichere Vorteile von TTK sind die deutlich geringere Spenderexposition der Empfänger und eine einfachere Logistik, wenn eine lückenlose Versorgung mit $\mathrm{ABO}$-gleichen und $\mathrm{Rh}$ kompatiblen TK angestrebt wird. Da die AB0-ungleiche Thrombozytentransfusion höchstwahrscheinlich mit einer deutlich höheren Morbidität und Mortalität einhergeht, ist die AB0-gleiche Transfusion anzustreben. Der wesentliche Vorteil von GTK liegt in den geringeren Herstellungskosten. Die Herstellung von GTK geht jedoch mit einem erheblichen Verlust an Plasma und Erythrozyten einher. Nur große, überregionale Blutspendedienste können eine lückenlose Versorgung mit $A B 0$-gleichen und Rh-kompatiblen GTK gewährleisten. Ob TTK wirksamer sind als GTK und ob der Einsatz von TTK mit niedrigeren Raten an bakterieller Sepsis einhergeht, wie einige Arbeitsgruppen zeigten, muss in künftigen prospektiven, kontrollierten Studien geprüft werden.

policies of 16 countries revealed substantial differences in the use of these platelet preparations [1]. Centers that use APC exclusively or that are using them increasingly maintain that alloimmunization occurs less frequently after transfusion of this type of platelet concentrate compared with PPC, with the added benefit that patients are exposed to the blood of fewer donors. In addition, apheresis platelets facilitate supply of al-

\begin{tabular}{ll}
\hline KARGER & $\oplus$ 2008 S. Karger GmbH, Freiburg \\
Fax +49 7614520714 & Accessible online at: \\
$\begin{array}{l}\text { E-mail Information@Karger.de } \\
\text { www.karger.com }\end{array}$ & www.karger.com/tmh \\
\hline
\end{tabular}

Prof. Dr. med. Peter Hellstern

Institut für Hämostaseologie und Transfusionsmedizin

Klinikum der Stadt Ludwigshafen

67063 Ludwigshafen, Germany

Tel. +49 621 50335-00, Fax -20

E-mail peterhellstern@medicusnet.de 
loimmunized patients with compatible platelets. Experts who combine the use of APC and PPC argue that PPC are less costly, and that the availability of apheresis donors is limited. This review focuses on differences between these 2 types of platelet concentrates in regard to clinical efficacy and adverse events, and on conclusions that should be drawn from these data with regard to platelet transfusion strategies.

\section{Clinical Success of Platelet Transfusion}

Several small studies have compared non-white blood cell (WBC)-reduced PPC with APC, noting no significant difference between APC and PPC in corrected count increments (CCI), recovery, or platelet survival. All of these studies however were either deficient in statistical power or suffered from flawed design [2-7]. Another prospective randomized trial examining posttransfusion platelet recovery and CCI of WBCreduced $\mathrm{PPC}$ and WBC-reduced APC in 115 patients noted a significantly increased success rate with APC after adjusting for platelet age [8]. The authors observed CCI values of $\geq 4.5 \times$ $10^{9}$ platelets $/ 1$ in $35 \%$ for the WBC-reduced PPC and in $53 \%$ for APC $(p<0.0001)$. The same study group performed a prospective crossover trial examining in vivo recovery and survival of autologous WBC-reduced apheresis platelets and autologous leukoreduced platelets prepared from whole blood, both preparations stored for 5 days, in 22 healthy volunteers [9]. The apheresis platelets had a $18.8 \%$ better recovery and survived $32.9 \%$ longer than did platelets prepared from whole blood. Finally, a small retrospective analysis of 105 PPC and 41 APC transfusions in 33 patients suffering from acute myeloid leukemia or myelodysplastic syndrome who had received allogeneic hematopoietic stem cell transplants demonstrated a significantly greater CCI after APC ( $p=$ 0.0001) [10]. However, the difference in refractoriness rates between the groups was not statistically significant due to the low number of observations (APC, 17\%; PPC, 30\%; $\mathrm{p}=0.1$ ).

\section{Donor Exposure}

One advantage of APC is that donor exposure to patients is reduced. At first sight, the use of PPC, which is prepared from 4 whole blood donations, would seem to increase donor exposure 4-fold compared to APC transfusion. Donor exposure would be 8 -fold if a patient required 2 therapeutic doses, which could conceivably be obtained from a single individual in the course of 1 plateletpheresis session. This difference in donor exposure between PPC and APC is already sufficient to wreck the increase in blood product safety gained through the introduction of nucleic acid amplification testing for HIV and HCV [11]. In Germany, about 150,000 PPC are produced annually from 620,000 whole blood units donated by 485,000 individuals [12]. Assuming that platelet transfusion policies aim- ing at minimal donor exposure might approach average annual donation frequencies of 20 APC per person, these 150,000 platelet concentrates could theoretically be obtained from a mere 7,500 donors, and total donor exposure might as a result be reduced by more than 60 -fold. Others deny that donor exposure is reduced by using APC since plateletpheresis donors are allowed to donate more frequently than whole blood donors and therefore - if infectious - might donate several times during the window period for the infectious agent, transmitting the agent to several recipients [13]. However, this scenario can to a large extent be avoided by establishing a minimal donation interval of 2 weeks, since the diagnostic window period for HCV and HIV has been almost completely closed subsequent to the introduction of minipool PCR testing after virus enrichment [14]. A risk assessment conducted by the Economics, Statistics and Operational Research Department (ESOR) of the English Department of Health has shown a reduced risk of transmission of variant Creutzfeldt-Jakob disease (vCJD) by transfusion when single-donor platelets are compared with PPC [1]. Replacing PPC with APC completely would also conserve about 37,000 l of whole blood plasma in Germany alone. About $100 \mathrm{ml}$ of red cells are wasted per 4 units of whole blood in the course of manufacturing PPC, adding up to 80,000 red cell concentrates per year.

\section{$\mathrm{ABO}$ and Rh Compatibility}

Several findings suggest that ABO-identical platelets should be used for transfusion wherever possible. Because A and B antigens express on platelet surfaces in subjects with corresponding blood groups, transfusing $\mathrm{ABO}$ incompatible platelets results in a substantial decrease in posttransfusion recovery and earlier onset of refractoriness [15-26]. The transfusion of group $\mathrm{A}$ and $\mathrm{AB}$ platelets to group $\mathrm{O}$ patients may reduce 1-hour posttransfusion platelet increment by up to $90 \%$ [15]. ABO-specific clinical refractoriness is frequently accompanied by an acute increase in isohemagglutinin titers [27, 28]. Reduced platelet recoveries may also occur after $\mathrm{ABO}$ minorincompatible platelet transfusions $[18,19,29]$. These observations have been ascribed to immune complexes composed of donor A or B antibodies and soluble A or B substances in the blood of the recipients. These immune complexes may bind to complement or Fc receptors on platelets, leading to accelerated immune clearance $[18,19]$. Early studies using nonleukodepleted platelet concentrates have shown that ABO-incompatible platelets can encourage HLA alloimmunization and the formation of platelet-specific antibodies [27, 30].

In the case of patients with acute myeloid leukemia or myelodysplastic syndrome who received either major or minor ABO-mismatched allogeneic bone marrow transplants, one study group attributed the increased rate of morbidity due to multiple organ failure or infection to platelet transfusions containing ABO-incompatible plasma [31, 32]. The risk of 
veno-occlusive disease in children treated with high-dose chemotherapy and hematopoietic stem cell transplantation for neuroblastoma or brain tumors has been found to be significantly associated with the transfusion of platelet concentrates containing ABO-incompatible plasma [33]. A retrospective study observed multiple ABO-mismatched platelet transfusions to be associated with unfavorable outcomes in cardiac surgery [34]. A second retrospective analysis in patients who had had cardiac surgery was not however able to confirm these findings [35]. Nevertheless, concern about ABO-incompatible platelet transfusions will remain until dispelled by results from prospective controlled trials.

Severe hemolysis has been observed after transfusion of outof-group platelet concentrates; particularly blood group $\mathrm{O}$ platelet concentrates to non-O patients [22, 25, 36, 37]. This can occur not only after transfusion of APC but also after PPC $[25,36]$. As hemolysis might be delayed and unrecognized clinically, underreporting may be a serious challenge [37]. Although the risk of anti-D formation after $\mathrm{RhD}$-incompatible platelet transfusions appears to be low [38-40], alloimmunization may occur even in immunocompromized recipients [41-43].

All these findings suggest that platelets should be transfused ABO-identically, and that RhD-negative children and women of childbearing age should receive $\mathrm{RhD}$-negative platelet units only whenever possible. In clinical practice however the use of PPC hampers the implementation of this platelet transfusion policy. Assuming a frequency of blood group A, RhDnegative of $6 \%$ in the German population, a series of at least 130 whole blood donations per day would be required to produce 2 group A RhD-negative PPC from 8 whole blood donations. Daily production would have to be no less than 3,400 whole blood units to supply 1 group $\mathrm{AB} \mathrm{RhD}$-negative patient with 2 anti-CMV-negative ABO-identical and RhD-compatible PPC. In contrast, these 2 platelet units can be obtained from 1 plateletpheresis session. These calculations explain why only major supraregional blood transfusion centers can guarantee full-coverage supply with $\mathrm{ABO}$-identical and $\mathrm{RhD}$-compatible PPC. But it is just these centers however that frequently fail to provide hospitals with compatible platelets without unacceptable delay.

\section{Non-Immune Causes of Platelet Refractoriness}

The Trial to Reduce Alloimmunization to Platelets (TRAP) examined the outcomes of 6,379 platelet transfusions given to 533 patients. It found reduced platelet refractoriness rates to be associated with transfusing filtered apheresis platelets [23]. This agrees with recent studies suggesting higher success rates after transfusion of APC compared with PPC [8, 9]. However, prospective controlled trials are needed to find out whether there are differences in clinical efficacy between leukodepleted PPC and APC or not.

\section{Bacterial Contamination}

Septic platelet transfusion reactions are supposed to result from platelet concentrates contaminated by donor skin flora or won from donors with asymptomatic bacteremia. Since the production of 1 APC involves only 1 venipuncture, but at least 4 venipunctures are needed to get 1 PPC from whole blood units, it would seem obvious that PPC carry the greater risk of transmitting bacterial infections to recipients. One retrospective study has suggested a substantial decrease in septic platelet transfusion reactions after increasing the frequency of APC use from 51.7 to $99.4 \%$ of all platelet transfusions [44]. This was however not confirmed by a more recent prospective multicenter trial comparing PPC and APC, which did not reveal any differences in bacterial contamination between both types of platelet units [45]. In the latter study, the initial 30-40 $\mathrm{ml}$ of apheresis and whole blood collections were diverted to a pouch. This pre-donation sampling obviously eliminated possible differences in bacterial contamination between PPC and APC.

\section{Further Aspects}

Alloimmunized patients require HLA and/or platelet-specific antibody-matched APC. The platelet count in APC can be adjusted more precisely and more flexibly than in PPC. If platelet function assays were available that would accurately predict the quality and clinical efficacy of platelet concentrates before the donation, these could be applied much more easily for APC than for PPC. Substituting PPC with APC conserves plasma and red cells obtained from whole blood donations.

\section{Conclusions}

Aside from the fact that APC are - perhaps - more expensive than PPC and the minor risk of severe adverse events involved in plateletpheresis, all aspects of platelet transfusion are in favor of APC. If future prospective controlled trials can demonstrate that APC is clinically more efficacious, replacing of PPC with APC would require fewer platelet concentrates. Using APC instead of PPC reduces patient donor exposure substantially. Relatively few regular plateletpheresis donors are required to supply patients with all blood group constellations. In view of the severe adverse events that can result from ABO-incompatible platelet transfusions, policies prescribing the use of ABO-incompatible platelet concentrates to avoid wastage should be prohibited. Replacing of PPC with APC would save substantial amounts of plasma and red cells obtained from whole blood. Unlike PPC, APC are biopharmaceutical preparations since platelet count can be adjusted precisely, and platelet quality can additionally be evaluated by predonation platelet function tests. 


\section{References}

1 International Forum: Logistics of platelet transfusion. Vox Sang 2007;92:160-181.

2 de Vries RA, de Bruin M, Marx JJ, Hart HC, Van de Wiel A: Viability of platelets collected by apheresis versus the platelet-rich plasma technique: a direct comparison. Transfus Med 1993;14:391398.

-3 Turner VS, Hawker RJ, Mitchell SG, Seymour Mead AM: Paired in vivo and in vitro comparison of apheresis and 'recovered' platelet concentrates stored for 5 days. J Clin Apher 1994;9:189-194.

4 Eriksson L, Kristensen J, Olsson K, Bring J, Högman CF: Evaluation of platelet function using the in vitro bleeding time and corrected count increment of transfused platelets. Comparison between platelet concentrates derived from pooled buffy coats and apheresis. Vox Sang 1996;70:69-75.

5 Klüter H, Dörges I, Maass E, Wagner T, Bartels H, Kirchner H: In-vivo evaluation of random donor platelet concentrates from pooled buffy coats. Ann Hematol 1996;73:85-89.

6 Strindberg J, Berlin G: Transfusion of platelet concentrates - clinical evaluation of two preparations. Eur J Haematol 1996;57:307-311.

7 Anderson NA, Gray S, Copplestone JA, Chan DC, Hamon M, Prentice AG, Johnson SA, Phillips M, van Waeg G, Oakhill A, Abeyasekera S, Pamphilon DH: A prospective randomized study of three types of platelet concentrates in patients with haematological malignancy: corrected platelet count increments and frequency of nonhaemolytic febrile transfusion reactions. Transfus Med 1997;7:33-39.

8 Heddle NM, Blajchman MA, Meyer RM, Lipton JH, Walker IR, Sher GD, Constantini LA, Patterson B, Roberts RS, Thorpe KE, Levine MN: A randomized controlled trial comparing the frequency of acute reactions to plasma-removed platelets and prestorage WBC-reduced platelets. Transfusion 2002;42:556-566.

9 Arnold DM, Heddle NM, Kulczycky M, Carruthers J, Sigouin C, Blajchman MA: In vivo recovery and survival of apheresis and whole blood-derived platelets: a paired comparison in healthy volunteers. Transfusion 2006;46:257-264.

10 Gurkan E, Patah PA, Saliba RM, Ramos CA, Anderson BS, Champlin R, de Lima M, Lichtiger B Efficacy of prophylactic transfusions using single donor apheresis platelets versus pooled platelet concentrates in AML/MDS patients receiving allogeneic hematopoietic stem cell transplantation. Bone Marrow Transplant 2007;40:461-464.

-11 Offergeld R, Faensen D, Ritter S, Hamouda O: Human immunodeficiency virus, hepatitis $\mathrm{C}$ and hepatitis B infections among blood donors in Germany 2000-2002: risk of virus transmission and the impact of nucleic acid amplification testing. Euro Surveill 2005;10:8-11.

12 Haschberger B, Waterkamp A, Heiden M, Seitz R: Bericht zur Meldung nach $\S 21$ TFG für die Jahre 2001 und 2002. Bundesgesundheitsbl Gesundheitsforsch Gesundheitsschutz 2005; 48:99-119.

13 Bosly A, Muylle L, Noens L, Pietersz R, Heim D, Hübner R, Selleslag D, Toungouz M, Ferrant A, Sondag D: Guidelines for the transfusion of platelets. Acta Clinica Belgica 2007;62:36-47.

14 Roth WK, Weber M, Buhr S, Drosten C, Weichert W, Sireis W, Hedges D, Seifried E: Yield of HCV and HIV-1 NAT after screening of 3.6 million blood donations in central Europe. Transfusion 2002;42: 862-868.
5 Aster RH: Effect of anticoagulant and ABO incompatibility on recovery of transfused human platelets. Blood 1965;26:732-743.

16 René J, Duquesnoy AJ, Tomasulo PA, Aster RH: ABO compatibility and platelet transfusions of alloimmunized thrombocytopenic patients. Blood 1979; 54:595-599. Heal JM, Blumberg N, Masel D: An evaluation of crossmatching, and $\mathrm{ABO}$ matching for platelet transfusions to refractory patients. Blood 1987;70:23-30.

17 Lee EJ, Schiffer CA: ABO compatibility can influence the results of platelet transfusion. Transfusion 1989;29:384-389.

18 Heal JM, Blumberg N, Masel D: An evaluation of crossmatching, HLA, and ABO matching for platelet transfusions to refractory patients. Blood 1987;70:23-30.

19 Heal JM, Rowe JM, Blumberg N: ABO and platelet transfusion revisited. Ann Hematol 1993; 66:309-314.

20 Klumpp TR, Herman JH, Innis S, Pearlman E, Culling N, Kotz KW, Slachta C, Goldberg SL, Mangan KF: Factors associated with response to platelet transfusion following hemaotpoietic stem cell transplantation. Bone Marrow Transplant 1996;17: 1035-1041.

21 Jimenez TM, Patel SB, Pineda AA, Tefferi A, Owen WG: Factors that influence platelet recovery after transfusion: resolving donor quality from $\mathrm{ABO}$ compatibility. Transfusion 2003;43:328-334.

22 Lozano M, Cid J: The clinical implication of platelet transfusions associated with $\mathrm{ABO}$ or $\mathrm{Rh}(\mathrm{D})$ incompatibility. Transfus Med Rev 2003;17:57-68.

23 Slichter SJ, Davis K, Enright H, Braine H, Gernsheimer T, Kao K, Kickler T, Lee E, McFarland J, McCullough J, Rodey G, Schiffer CA, Woodson R: Factors affecting posttransfusion platelet increments, platelet refractoriness, and platelet transfusion intervals in thrombocytopenic patients. Blood 2005;105:4106-4114.

24 Aboul Enein A, Hussein EA, Hallouda M: Factors affecting platelet yield and their impact on the platelet increment of patients receiving single donor PLT transfusion. J Clin Apheresis 2007;22: 5-9.

25 Cid J, Lozano M: Lower or higher doses for prophylactic platelet transfusions: results of a metaanalysis of randomized controlled trials. Transfusion 2007;47:464-470.

26 Cooling L: ABO and platelet transfusion therapy. Immunohematology 2007;23:20-33.

27 Carr R, Hutton JL, Jenkins JA, Lucas GF, Amphlett NW: Transfusion of ABO-mismatched platelets leads to early platelet refractoriness. $\mathrm{Br} \mathrm{J}$ Haematol 1990;75:408-413.

28 Ishibashi M, Oshida M, Kurata Y, Kokado Y, Takahara S, Kyo M, Ikoma F: Immunologic low-responder in ABO-incompatible renal transplant recipients explored by donor-specific platelet transfusion. Transplant Proc 1998;30:2298-2299.

29 Heal JM, Masel D, Blumberg N: Interaction of platelet Fc and complement receptors with circulating immune complexes involving the ABO system. Vox Sang 1996;71:205-211.

30 Duquesnoy RJ, Anderson AJ, Tomasulo PA, Aster $\mathrm{RH}$ : ABO compatibility and platelet transfusions of alloimmunized thrombocytopenic patients. Blood 1979;54:595-599.

31 Benjamin RJ, McGurk S, Ralston MS, Churchill $\mathrm{WH}$, Antin JH: ABO incompatibility as an adverse risk factor for survival after allogeneic bone marrow transplantation. Transfusion 1999;39:179-187.
2 Benjamin RJ: ABO-incompatible bone marrow transplantation: the transfusion of incompatible plasma may exacerbate regimen-related toxicity. Transfusion 1999; 39:1273-1274.

33 Lapierre V, Mahé C, Aupérin A, Stambouli F, Oubouzar N, Tramalloni D, Benhamou E, Tiberghien P, Hartmann O: Platelet transfusion containing $\mathrm{ABO}$-incompatible plasma and hepatic veno-occlusive disease after hematopoietic transplantation in young children. Transplantation 2005; 314-319.

34 Blumberg N, Heal JM, Hicks GL, Risher WH: Association of ABO-mismatched platelet transfusions with morbidity and mortality in cardiac surgery. Transfusion 2001;41:790-793.

35 Lin Y, Callum JL, Coovadia AS, Murphy PM: Transfusion of ABO-nonidentical platelets is not associated with adverse clinical outcomes in cardiovascular surgery patients. Transfusion 2002;42: 166-172.

36 Fung MK, Downes KA, Shulman IA: Transfusion of platelets containing ABO-incompatible plasma. Arch Pathol Lab Med 2007;131:909-916.

37 Harris SB, Josephson CD, Kost CB, Hillyer CD: Nonfatal intravascular hemolysis in a pediatric patient after transfusion of a platelet unit with hightiter anti-A. Transfusion 2007;47:1412-1417.

38 Goldfinger D, McGinniss MH: Rh-incompatible platelet transfusions - risks and consequences of sensitizing immunosuppressed patients. N Engl J Med 1971;284:942-944.

39 Cid J, Ortin X, Elies E, Castellà D, Panadés M, Martín-Vega C: Absence of anti-D alloimmunization in hematologic patients after D-incompatible platelet transfusions. Transfusion 2002;42:173-176.

40 Molnar R, Johnson R, Sweat LT, Geiger TL: Absence of D-alloimmunization in D- pediatric oncology patients receiving D-incompatible single-donor platelets. Transfusion 2002;42:177-182.

41 McLeod B, Piehl MR, Sassetti J: Alloimmunization to RhD by platelet transfusions in autologous bone marrow transplant recipients. Vox Sang 1990;59: 185-189.

42 Ewing CA, Rumsey DH, Lanfberg AF, Sandler SG: Immunoprophylaxis using intravenous $\mathrm{Rh}$ immune globulin should be standard practice when selected D-negative patients are transfused with D-positive random donor platelets. Immunohematology 1998; 14:133-137.

43 Atoyebi W, Mundy N, Croxton T, Littlewood TJ, Murphy MF: Is it necessary to administer anti-D to prevent $\mathrm{RhD}$ immunization after the transfusion of RhD-positive platelet concentrates? Br J Haematol 2000;111:980-983.

44 Ness P, Braine H, King K, Barrasso C, Kickler T, Fuller A, Blades N: Single-donor platelets reduce the risk of septic platelet transfusion reactions. Transfusion 2001;41:857-861.

45 Schrezenmaier H, Walther-Wenke G, Müller TH, Weinauer F, Younis A, Holland-Letz T, Geis G, Asmus J, Bauerfeind U, Burkhart J, Deitenbeck R, Förstermann E, Gebauer W, Höchsmann B, Karakassopoulos A, Liebscher UM, Sänger W, Schmidt M, Schunter F, Sireis W, Seifried E: Bacterial contamination of platelet concentrates: results of a prospective multicenter study comparing pooled whole blood-derived platelets and apheresis platelets. Transfusion 2007;47:644-652. 